\title{
Edebî bir tür olarak falnâme ve mensûr bir Kur'ân falı örneği
}

\section{Semih YEȘILBAĞ $\mathbf{1}$}

APA: Yeşilbağ, S. (2020). Edebî bir tür olarak falnâme ve mensûr bir Kur'ân falı örneği. RumeliDE Dil ve Edebiyat Araştırmaları Dergisi, (Ö7), 367-379. DOI: 10.2900o/rumelide.808730.

\section{$\ddot{\mathbf{O} z}$}

Her devirde insanların en azından hayatlarının bir döneminde evlenmek, bir işe başlamak, farklı bir diyara taşınmak gibi önemli kararlar eşiğindeyken nasıl hareket etmelerinin kendileri için daha iyi olacağını, kararlarının olumlu sonuçlar getirip getirmeyeceğini bilmeyi istedikleri olmuştur. Çoğunlukla bu geleceğe matuf istek ve umut; onları içine düştükleri belirsizlik ve kararsızlıkta farklı olay, nesne ve durumlardan kendilerine çıkış yolunu gösterdiğine inandıkları işaretler bulma arayışına yönlendirmiştir. Bunun neticesi olarak tarih içerisinde bazı insanlar; yıldızlardan kuşların türlerine, uçuş veya ötüş şekillerine; hayvanların kürek kemiğinden insanın avuç içindeki çizgilere; içilen bir kahvenin fincanda bıraktığı izlerden kutsal kitaplara kadar çok farklı unsuru aradığı cevabın işaretlerini bulabilmek için kullanmıştır. Bulduğunu düşündüğü bu işaretlerin kimilerinin iyiliğin; kimilerinin de kötü şeylerin habercisi olduğuna inanmış ve ona göre hareket etmiştir. İşte en genel ifadeyle bu işaret arama işi fal; mevzusu fal olan eserler falnâme; işaret arama işinin Kur'ân-ı Kerîm kullanılarak yapılan türü de Kur'ân falı olarak değerlendirilebilir. Bu çalışmada üzerinde inceleme yapılan falnâme, Millî Kütüphane'de o6 Mil Yz A 2703/1 demirbaş numarasıyla kayıtlı eser içerisinde yer alan bir Kur’ân falı örneğidir. Çalışmada falın ve falnâmelerin tanımı, özellikleri, tarihi arka planı hakkında genel bilgiler verilmiş, inceleme yapılan falnâmenin hususiyetleri üzerinde durulmuş, falnâme çeviri yazıya aktarılmış; son olarak da incelenen falnâmenin orijinal metnine ait görseller eklenmiştir.

Anahtar kelimeler: fal, falnâme, Kur’ân falı, tefe“ül

\section{Falnâma as a literary genre and a prose Quran fortune-telling example}

\begin{abstract}
In every era, people have wanted to know at least in one period of their lives how it will be better for them to act or whether their decisions will bring about positive results when they are on the verge of an important decision such as getting married, starting a job or moving to a different place. This wish and hope for the future have mostly led them to find some signs that they believe will show them a way out of different events, objects and situations in the uncertainty and indecision they have fallen into. As a result of this, some people have used very different elements from stars to birds' types and flight or singing patterns, from the scapulas of animals to lines on the palms of humans and from the marks left by a cup of coffee to holy books to find the signs of the answers they are looking for. They have believed that some of these signs they thought they have found were messengers of goodness, while some were messengers of bad things and they have acted accordingly. In most general terms, this search for signs can be evaluated as fortune telling, works the subject of which are fortune-telling can be evaluated as falnâma (fortune book); while the
\end{abstract}

$1 \quad$ Dr. Öğr. Üyesi, Ondokuz Mayıs Üniversitesi, Fen-Edebiyat Fakültesi, Türk Dili ve Edebiyatı Bölümü, Eski Türk Edebiyatı ABD (Samsun, Türkiye), syesilbag@hotmail.com, ORCID ID: oooo-ooo1-9219-3601 [Makale kaylt tarihi: 20.08.2020-kabul tarihi: 20.10.2020; DOI: 10.29000/rumelide.808730] 
search for signs done by using Quran can be evaluated as Quran fortune-telling. Falnâma, which was analysed in the present study, is an example of Quran fortune-telling included in the work registered to National Library with the stock number 06 Mil Yz A 2703/1. The study gives general information about the definition, characteristics and historical background of fortune-telling and falnâma, analyses the characteristics of the falnâma examined, the falnâma was transcribed and lastly images of the original text of the analysed falnâma were added.

Keywords: fortune-telling, falnâma, Quran fortune-telling, tefe'ül

\section{Giriş}

Tarihin her döneminde ve tespit edilebildiği kadarıyla her toplumda insanoğlunun bilinmeyeni bilmeye, gelecekte olacaklardan haberdar olmaya karşı ilgisi olmuştur. Bu ilginin neticesi olarak da insanoğlu; birtakım durum, nesne ya da olaylardan aklındaki soru işaretlerini giderici anlamlar çıkarma çabası içerisinde olagelmiştir. Bu çaba, aslen uğur; tâlih deneme; kahve fincanına, iskambile bakmak gibi birtakım garip usullerle insanın tâlihine âit şeyler söyleme (Devellioğlu, 2013: 286); özellikle gayb, gelecek ve insan karakteri hakkında bilgi verme amacı taşıan bütün esrarengiz faaliyetler (Çelebi, 1995: 138); gelecekten haber almak için çeşitli nesnelerden anlam çıkarma (Hançerlioğlu, 2000: 152) şeklinde tanımlanabilecek olan "fal" inanışını ortaya çıkarmıştır.

Bugün ortaya konan belgeler ışığında milattan önce 4000 ylllarından itibaren Çin, Mısır, Babil, Eski Yunan gibi geçmiş medeniyetlerde falcıllğın önemli görüldüğü, din ve hekimlikle bağlantılı olduğu, hatta kişisel veya toplumsal meselelerin çözümünde başvurulan başlıca yardımcılardan kabul edildiği bilinmektedir. Bazen de Mısır'da olduğu gibi fal ile sihrin iç içe olduğu görülmektedir. (Ersoylu, 1981: 69)

Kadîm bir geçmişe sahip olan Türklerde de fal ve falcılık ile ilgili ilk uygulamalar, çok eskilere dayanmaktadır. Bugün için ele geçen en eski belgelerden biri olan Türkçenin 9. yüzyllda Köktürk harfleriyle kâğıt üzerine yazılmış ilk eseri konumundaki Irk Bitig adlı eserin bir fal kitabı olması, bu fikri güçlendirmektedir.

Eski Türkçede "fal” kelimesinin anlam kapsamına girecek biçimde kullanılmış olan bazı kelimelerin izini sürmek de falın farklı Türk toplumlarındaki yerini ve geçmişini göstermesi bakımından önemlidir. Sözgelimi eski Türkçede "işaret, rumuz, falcı" için ırk kelimesi kullanılır. Uygurcada "rrkla-" fiili falcıdan sormak anlamına gelmektedir. (Caferoğlu, 1968: 87) Dîvânü Lügati’t-Türk’te ırk kelimesi; falcılık, kâhinlik ve bir kimsenin gönlündekini bilmek anlamında kullanılmıştır. (Atalay, 1985: 42) Kıpçak lehçelerinde teşe"üm ve tefe"ül anlamlarına gelen $\mathrm{rrm}$ kelimesi de kök itibariyle rrk kelimesi ile ilgilidir. Altay şamanistlerinde kamdan başka inanılmıştır. Şamanistlerin ve Kırgızların fal anlamında tölge kelimesini kullandıkları da bilinmektedir.

Eski Türklerde falcılar da fal bakmak için kullandıkları nesneye göre değişik isimler alırlar. Türkler arasında en yaygın fal olan kürek kemiği falına bakan kişiye yağrıncı, koyun tezekleriyle fal açanlara kumalakçı, değişik şeylerden anlamlar çıkaran falcılara ırımçı denir. (İnan, 1986: 151-152) Türklerde genel olarak daha çok suya ve aynaya bakma; kurşun, köz ve tütsü; kürek kemiği, bakla ve kahve fallarının; Orta Asya Türkleri arasında ise koyun ve keçinin kürek kemiğiyle fala bakma âdetinin benimsenip yaygın olarak kullanıldığı; hatta falın Türk kültüründe kimi zaman sihir ve büyü ile birlikte 
yürütüldüğü görülmektedir. (Şenödeyici ve Koşik, 2017: 18) İslamiyet’in kabulüyle birlikte Türk geleneğinde var olan kimi fallar terk edilmiş, kimileri ise İslamî renge bürünerek varlı̆̆ını devam ettirmiştir. (Ertaylan, 1951: 1)

Siyer ve İslâm tarihi kaynaklarından edinilen bilgiler, Araplar arasında da özellikle Cahiliye döneminde fal geleneğinin yaygın bir şekilde mevcut olduğunu göstermektedir. Bu fallardan biri ezlam denen yedili fal oklarıdır. Mekkelilerin Kâbe'nin içinde bulunan Hübel adlı putun yanında veya kâhinlerle hakîmlerin nezdinde bulunan ve her biri "evet", "hayır", "sizden”, "başkasından", "açlk değil", "diyet", "su” ifadelerinden biri yazılmış olan yedi oka dayalı bir fala başvurdukları bilinmektedir. Bir işi yapmak ya da yapmamak, nesebi şüpheli görülen çocuğun babasını tespit etmek, öldürülen kişinin diyetini ödetmek, su kuyusu açmak, evlenmek gibi önemli durumlarla ilgili olarak kısmetini belirlemek isteyen kişi, hediyelerle Kâbe'nin hizmetçisine ya da yedi oku bulunan kâhinlere gider, kısmet çektirir ve ona göre hareket ederdi. (Öz, 1995: 67) Hatta böylesi bir uygulamaya peygamberimizin dedesi Abdülmuttalib’in de başvurduğu bilinmektedir.

Kısaca bu hadiseden bahsedilecek olursa olay şöyledir: Cürhümlülerin Mekke'yi terk ettikleri sırada kapattıkları zemzem kuyusunu Abdülmuttalib, kabilesinin reisliğini yaptığı dönemde, gördüğü bir rüya üzerine açmak ister. Bu sırada Haris’ten başka oğlu olmadığı için bu kararına muhalefet edenlere karşı fikrini savunurken büyük zorluk yaşar. Kendisine destek olacak erkek evlat eksikliğini çok hisseder ve on oğlu olduğu takdirde birisini kurban edeceği adağında bulunur. Gerçekten de ilerleyen dönemde on oğlu olur ve adağının gereğini yerine getirmek üzere harekete geçer. Hangi oğlunu kurban edeceğini belirlemek üzere çektiği kurada Peygamberimizin babası Abdullah çıkar. Abdullah'ın kurban edilmesini istemeyen Kureyş’ten bazı kişilerin yönlendirmesiyle Abdülmuttalib, gittiği bir kâhinden bir kişinin diyetinin on deve olduğu bilgisini öğrenir, kurayı yenilemek üzere art arda çektiği fal oklarından da Abdullah ismi çıkıp ancak on birinci kurada "deve" yazılı fal oku çıkması üzerine oğlu Abdullah’ın hayatı karşllı̆̆ında yüz deveyi kurban eder. (Yıldız, 2010: 182)

İslam dininin emirlerini oluşturan Kur'ân ayetlerinin Hz. Peygamber aracıllğıyla tebliğ edilmesiyle o günkü Arap toplumunda var olan birçok cahiliye inanç, âdet ve yaşantısı gibi fal da yasaklanmıştır. Aslında Kur'ân'da fal kelimesi yer almamakta, kuşların ötüşünden ve uçuşlarından hareketle geleceğe dönük olumsuz anlamlar çlkarma demek olan tıyere kelimesi geçmektedir. Fal ve falcılık anlamına gelebilecek veya kapsamına girebilecek her şey, "Ey iman edenler! (Akl örten) içki (ve benzeri şeyler), kumar, dikili taşlar ve fal okları ancak şeytan işi birer pisliktir. Onlardan kaçının ki kurtuluşa eresiniz.” (Mâide 5/90), “...fal oklarıyla kısmet aramanız size haram kılındı...” (Mâide 5/3) ayetleriyle yasaklanmıştır. Ayrıca fala inanan ve falda çıkanlara itibar edenlerin namazlarının kırk gün kabul olunmayacağını, üstelik bunların vahyi ve kitabı inkâr etmiş olacaklarını ihtiva eden hadisler de mevcuttur. (Topal, 2011: 251)

Bu konudaki diğer bazı hadislerden de bahsedilecek olursa, Ebû Hureyre'den nakledilen hadislere göre Hz. Peygamber'in; "Eşyada uğursuzluk yoktur; tıyerenin hayırlısı tefe "üldür." buyurduğu, mecliste bulunanlar "Tefe "ül nedir yâ Resûlullah?" diye sorduklarında cevaben "Sizin birinizin işiteceği güzel sözdür." (Buhârî, 1998: 5776) dediği; yine başka bir hadiste Hz. Peygamber'in; "(İslam'da) advâ ve tıyere inancı yoktur. İyi ve güzel kelime olan fal, benim hoşuma gider.” (Buhârî, 1998: 5778) buyurdukları da bilinmektedir. Bu hadislerin kayıtlı olduğu Sahîh-i Buhârî kitabının ilgili sayfasındaki dipnotta şu bilgilere de yer verilmektedir: Tiyere kendisiyle teşe“üm olunan yaramaz fala denir. Hadisteki tıyere bir maksadı yapmak üzere evinden çıkan yolcunun önünden kuş yâhud bir hayvan geçmesiyle, bunu uğursuzluk sayıp maksadına gitmekten vazgeçip geri dönmesidir ve bu durumun 
cahiliye âdetlerinden olduğu bilinmektedir. Diğer bir dipnotta da şu bilgi yer almaktadır: Teşe“üm bir şeyi uğursuz, hayırsız saymaktır, tefe “ül de bir şeyi hayırlı ve uğurlu saymaktır. Güzel sözle tefe"üle en güzel misal, Hudeybiye'deki müzakereler sırasında Süheyl ibn Amr'ın gelişi duyulunca Resûlullah'ın "Süheyl” ismiyle tefe“ül ederek “İşimiz kolaylaştı.” buyurmalarıdır. (Buhârî, 1998: 5776-5777)

Rivayetlerine yer verilen bu bilgiler ışığı altında Hz. Peygamber'in bugün faldan anladığımız, "gelecekten olumlu veya olumsuz haberdar olmak" anlamındaki fal’ı değil, "güzel falı, yani güzel söz anlamına gelen "fal-ı salih"i sevdiği, Allah’tan ümit ve arzu içinde olunarak duyulan bir sözü, hayra yorma olan tefe "ülü istisna tuttuğu söylenebilir. Zaten gerek dinî kurallarla yönetilen diğer İslam beldelerinde gerekse Osmanlı Devleti'nde fal-i salih’in/tefe“ül'ün varlık göstermeye devam etmesinin Hz. Peygamber’in yukarıda zikredilen hadisleriyle ilgili olduğu söylenebilir. Tabiî Hz. Peygamber’in tefe“ül ettiği hakkında rivayetler olmasına rağmen, Kur'ân'la tefe“ül ettiğine dair bir bilgi tespit edilememiştir. Aslında Peygamberimizin bazı işlerin hayırlı olup olmadığını anlamak için tefe"ül değil, iki rekat namaz kılıp duasını okuyarak uykuya yatıp rüyadan yol gösterici işaret görme anlamına gelen istihareyi ashabına öğretip tavsiye ettiği kaynaklarda yer almaktadır. (Ayrıntlı bilgi için bkz. Buhârî, 1998: 1109-1110)

Yine de Hz. Peygamber’in insana ümit verici olumlu yönü hasebiyle tefe“ülü, içerisinde olumsuz çıkarımlar barındıran tıyereden/teşe"ümden ayırıcı tavrının, tefe"ülün Müslüman halk arasında yaşamasını sağladığı; hatta ilerleyen dönemlerde tefe“ül kavramının kapsamının daha genişletilerek içerisine Kur'ân'ın da dâhil olduğu bazı kitaplarla olumlu işaretler aramak için tefe “ül yapılması uygulamalarına ilham kaynağı olduğu da düşünülebilir.

Sonraki dönemlerde Gazâlînnin (ö. 505/1111) fal kelimesini, teberrük kelimesinin eş anlamlısı olarak kullanması ve İhyâü Ulûmi'd-dîn adlı eserinin mağfiret bahsiyle bitmesini hayatın saadetle neticeleneceği yönünde hayırlı bir fal olduğunu belirtmesi (Macdonald, 1988: 450); iyi yetişmiş, donanımlı bir padişah olan Fatih Sultan Mehmed'in (ö. 886/1481) kendisi için fal kitabı yazdırması, Şeyhülislam Ebussuûd Efendi’nin (ö. 982/1574) Kur'ân'la tefe“ül etmenin cezaî bir müeyyideyi gerektirmediğini belirtmesi (Sezer, 1998: 13) gibi bazı durumların da bu olumlu bakış açısının yansımaları olduğu söylenebilir.

Edebî kavram olarak tefe “ül, özellikle kitap falı olarak bilinir. İslam dünyasında daha çok ilmî ve fikrî hayatın durakladığı dönemlerde Kur'ân-ı Kerim, Divan-ı Hâfız, Mesnevî, Ahmediye, Muhammediye ve Envârü'l-Âşıkîn gibi kitaplarla fal açıldığı; hatta İran'da bazı Kur'ân-ı Kerimlerin sonuna beş on sayfalık falnâmelerin ve bu falları değerlendirme cetvellerin ilâve edilerek basıldığı da bilinmektedir. (Çelebi, 1995: 139)

Falnâme, fal kitaplarına verilen ad (Pala, 1995: 179); fal bakmaya yarayan, mistik folklorun gereği olarak anlaşılması kolay bir dille yazılmış resimli ve resimsiz, tıbbî folklora ait telkine dayalı kitaplar (Karataş, 2001: 141); falın nasıl bakılacağını, nasıl yorumlanacağını anlatan ya da özel fal formülleri veren kitaplar (Sezer, 1998: 15) şeklinde tanımlanabilir. Sadece manzum, sadece mensur veya manzum-mensur karışık olarak Arapça, Farsça ve Türkçe yazılanlarına rastlanabilen bu eserlerde genel bir hususiyet olarak fala başlanmasından önce abdest almak, iki rekât namaz kılmak, belirli ayetleri veya duaları okumak şeklinde uygulamalar yapıldığı görülür. Falnâmelerin başında "Gaybı ancak Allah bilir.” hükmü yazılı olabileceği gibi, fal bakmak suretiyle yapılacak işin olayları hayra yormaktan ibaret olduğu ekseriyetle vurgulanmıştır. (Uzun, 1995: 141) 
Falnâmelerin genellikle Hz. Ali'ye, Cafer-i Sadık'a, Muhyiddin Arabi'ye; kimi zaman da Hz. Fatıma'ya dayandırıldığı görülmektedir. Ancak bu eserlerin bu kişilere ait olması, gerçeklikten uzak bir ihtimal olup bu eserlerin bahsi geçen kişilerin manevî otoriteleri dolayısıyla kendilerine izafe edildikleri söylenebilir. (Uzun, 1995: 142)

Falnâmeler, geleceği bildirmekten ziyade, insana tereddüte düştüğü bir mevzuyla ilgili harekete geçebilme cesareti verir. Ayrıca fal bakılırken çıan sonuçların hayra yorulması gereklidir. Aksi durumda yapılan iş; tefe"ül (hayra yorma) değil, teşe“üm (kötüye yorma) olur. (Şenödeyici ve Koşik, 2017: 28)

$\mathrm{Bu}$ metinler, dinî kitaplardan birtakım çıkarımlarda bulunma, kura yöntemiyle peygamber, şehir, kabile, ağaç isimleri gibi birçok unsurun işaret ettiği anlamlara dair yorumlar yapma gibi çok farklı uygulamalardan oluşabilmektedir. (Gür, 2012: 204)

Falnâmeler, genellikle sanat amacı gütmeden, yalın bir dille halk için yazılan eserler olmalarına rağmen içlerinde sanat eseri hüviyetinde edebî olarak kaleme alınanları da vardır. Falnâmelerin padişah ve devlet adamlarıyla ileri gelen kişilere sunulan nüshaları, tanınmış hattat ve müzehhiplerin elinden çıktığı gibi bazılarına minyatür, resim ve şekiller de ilave edilmiştir. (Uzun, 1995: 141)

Ömer Rûşenî Dede'nin Miskinnâme'si, Cem Sultân'ın Fâl-ı Reyhan'ı, Hamdullah Hamdi ve Erzurumlu İbrahim Hakkı'nın Kıyâfetnâme adlı eserleri edebiyatımızda fal konusunun müstakil olarak işlendiği akla ilk gelen örneklerdir. (Kurnaz, 1997: 183)

Müstakil bir eser olmayıp mecmuaların ve cönklerin bir bölümü içerisinde yer alan falnâmelere de sıklıkla rastlanmaktadır. Bu falnâmelerin farklı şekillerdeki çalışmalara konu olduğu görülmektedir. Söz gelimi fal kavramı, fal geleneği, falcıların şahsi özellikleri ve başlıca fal çeşitleri başlıklarıyla meseleyi ele alan eser tez (Duvarcı, 1987); Kur'ân falları, bu fallara bakma usullerini ele alıp Uzun Firdevsî̀ye ait bir falnâme örneğini inceleyen eser kitap formunda (Şenödeyici ve Koşik, 2017) karşımıza çıkmaktadır. Ancak falnâmelerin genellikle orijinal metinleri de ilave edilerek daha çok makale bünyesinde neşredildiği görülmektedir. Bunların birkaçından bahsedilecek olursa, bazı özel isimler üzerinden niyet tutma ve kura falı niteliğinde olup fal uygulama şeması da olan 33 bendlik manzum falnâme (Gülhan, 2015: 195-222); Fedâyînin divanının sonunda yer alan "Fal-nâme-i Kur'ânI Azîm" adlı 78 beyitlik bir falnâme (Şanlı, 2013: 161-178); tefe“ülde bulunmanın şekillerini gösteren ve arkaik unsurlar açısından da zengin manzum falnâme (Vural, 2017: 95-114); iki bölümden oluşan eserin birinci bölümünde Arap alfabesine göre sırasıyla tefe"ül sonucunda tespit edilen harflerin hangi manaya geldiğini açılayan, ikinci bölümünde ise "fâl-ı tekrâr" başlığı ile tefe"ül sonucunda aynı harflerin tekrar gelmesinin yorumlarına yer veren falnâme (Temizkan, 2007: 70-74), Fâl-ı Kur'ân-ı Azîm isimli Arap alfabesindeki her bir harf ile ilgili tefe"ül yorumlarına yer verilmesiyle oluşan manzum falnâme (Şenödeyici ve Koşik, 2015: 71-96) bu minvalde neşredilen bazı makalelerdir.

Yukarıda zikri geçen veya farklı falnâmelere bakıldığında tefe “ül yapmanın çeşitli usulleriyle karşılaşılmaktadır. Kutsal kitapların, tanınmış şairlerin divanlarının veya dinî, tasavvufî eserlerin bir niyet veya dilek tutularak rastgele açılması neticesinde göze ilk çarpan ifadeyi okuyup yorumlamak (Bilkan, 2010: 133); Kur'ân'ı kapalı gözlerle açıp çıkan sayfadan yedi sayfa gerisini saymak ve burada göze ilk görünecek ayetten mana çıkarmak (Pakalın, 1993: 586); Kur'ân'ı açtıktan sonra sayfadaki yedinci satıra bakıldığında göze çarpan ilk harfi dikkate almak; Kur'ân’ı açınca sağ taraftaki sayfaya dikkatlice bakıp tespit edilen "Allah" kelimesi sayısınca sol taraftaki sayfadan çevirerek yine aynı sayı 
kadar satırı yukarıdan aşağı doğru saydıktan sonra varılacak satırın birinci harfini hesaba almak gibi ve daha değişik usullerle tefe"ül yapıldığına rastlanmaktadır. (Ersoylu, 1997: 199)

Makalemize de konu olan falnâmede tefe"ülün yapılma şeklinin metinde belirtilmemesi, bu falnâmenin tefe"ül şeklinin; tefe"ülde en genel olarak karşılaşılan usullerden olan Kuran'ın bir sefer açılması ve göze çarpan ilk kelimenin ilk harfinin yorumlanması usulüne dayalı bir Kur'ân falı olabileceği izlenimi vermektedir.

Falnâmeler üzerine yazılan eserlerde falnâmelerin farklı bakış açlarıyla tasnif edildikleri de görülmektedir. Sözgelimi TDV İslam Ansiklopedisi'nin "falnâme" maddesinde fal bakılmasında kullanılan metinlere göre falnâmeler üç gruba ayrılmıştır: 1. Kur'ân Falnâmeleri 2. Kura Falnâmeleri 3. Peygamberler Adına Düzenlenen Falnâmeler (Uzun, 1995: 142-143) Osmanli’nın Gizemli İlimleri kitabında falnâmeler konularına göre; 1. Kur'ân Falları 2. Kur'a Falları 3. Peygamber Adı Falları 4. Yıldıznâmeler 5. Kıyafetnâmeler 6. İhtilacnâmeler (Şenödeyici ve Koşik, 2017: 24-26) şeklinde altı başlık altında değerlendirilmiştir. Osmanlı'da Fal ve Falnâmeler adlı eserde ise Osmanlı dönemi falnâmelerinin şu üç bölüme ayrllarak incelendiği görülmektedir: 1. Kur'ân Falları, 2. Kitap Falları, 3. Kura Fallart (Sezer, 1996: 18)

Falnâmeler, farklı alt başlıklara ayrılabilse de üzerinde inceleme yaptığımız falnâmenin bir Kur'ân fah olması hasebiyle bu makalede sadece Kur'ân falları hakkında genel birtakım bilgiler verilmiş, diğer falnâme türleri üzerinde ayrıntılı olarak durulmamıştır.

Kur'ân fallarının falnâme başlığı altında toplanan fallar içinde yaygın bir kullanımı olduğu görülmektedir. Kur'ân falları ilk olarak Araplarda görülmüş; daha sonra İranlılar ve Türkler, Kur'ân falı içerikli manzum veya mensur eserler meydana getirmişlerdir. (Ylldız, 2010: 183)

Kimi eserlerde Kur'ân fallarının Cafer-i Sadık, Hz. Ali veya Hz. Peygamber'den geldiği belirtildiği gibi kimisinde de bu fala inanmayanlara Müslüman denmeyeceği gibi keskin ifadelerin yer aldığı da görülmektedir. (Yıldız, 2010: 183) Bu durumun fala muhatap olan kişide fal ve falcıllğa karşı var olabilecek tereddütleri gidermek için başvurulan bir yaklaşım olduğu düşünülebilir.

Kur’ân fallarının da farklı değerlendirme ölçütlerine göre kendi içerisinde bir gruplandırılmaya tabi tutulduğu görülmektedir. Söz gelimi "Klasik Türk Edebiyatında Tefe"ül Geleneği ve Kitap Falının Şiire Yansıması" adlı makalede Kur'ân Falının 1. Harflere Dayalı Tefe"ül, 2. Surelerle İlgili Tefe“ül, 3. Ayetlerle Tefe “ül şeklinde üçe ayrıldığı görülmektedir. (Dikmen ve Çetin, 2016: 195-198) Bu tasnif, değerlendirmede tefe"ülde tespit edilen harfin, ayetin veya surenin tefe"ül cetveline göre yorumuna dayanmaktadır. Osmanlı'da Fal ve Falnâmeler (Sezer, 1998: 18-35) adlı eserde ise Kur'ân fallarının Kur’ân-ı Kerim'in eserde belirtilen usule göre bir sefer açlışına ya da birden fazla açılışıyla ortaya çlkan harf gruplarının yorumuna dayanan 1. Tek Harf Yorumlu Falnâmeler, 2. Harf Grubunu Yorumlayan Falnâmeler şeklinde iki gruba ayrıldığı görülmektedir.

$\mathrm{Bu}$ tasnifler dikkate alındığında, makalede incelenen falnâmenin ilk tasnife göre, harflere dayal tefe“ül; diğer tasnife göre de tek harf yorumlu falnâmeler içerisinde yer aldığı söylenebilir.

İnceleme yaptı̆̆ımız "Hâzâ Kitâb-ı Fâlnâme" başlıklı falnâme, Millî Kütüphane'de o6 Mil Yz A 2703/1 demirbaş numarasıyla kayıtlı olan eserin 1b-3b varakları arasında bulunmaktadır. 230x133153x85mm ölçülerinde, şemseli kahverengi meşin bir cilt içerisinde beyaz cedid kâ̆ğtt üzerine harekeli nesih hatla yazılmış, tespit edilebildiği kadarıyla tek nüsha olan mensur bir eserdir. Eserin müellifi ve 
müstensihi bilinmemektedir. Eserde Kur'ân falının yazılış tarihi hakkında da herhangi bir kayıt bulunmamaktadır.

Çeviri yazılı metnin hazırlanması aşamasında falnâmenin orijinal imlasına ayet iktibasları kısmı hariç sadık kalınmış, metnin okunuşunda harekelere azami derecede dikkat edilmiştir. Bağlamına göre eksiklik olduğu düşünülen yerlerde metne tarafımızdan yapılan eklemeler, köşeli parantez içinde "[ ]" yazılmıştır.

Falnâmede bir niyet tutulup kıbleye karşı diz çökülerek Âyete’l-Kürsînin okunması, üç kez salavat getirilmesi ve "Bismillāhi' r-rahmāni'r-rahịm Allāhümme inni tekabbeltü bi-kitābike'l-kerīm ve tevekkeltü 'aleyke fe-erini min-kitābike mā-hüvel mektūbi fï-sirrike'l-meknūni fï-ğaybike Allāhümme ente'l-hakku enzelehü 'aleyke'l-hakkü' duasının üç kez okunması gerektiği gibi açlklamalar yapılmaktadır. Buna karşın harf yorumuna dayalı olan falnâmede yorumlanacak harfin nasıl tespit edileceğine (tefe"ülün yapılışı) dair bir bilgiye yer verilmemiştir.

Metinde tefe"ülle tespit edilen harfin ne manaya geldiğini açıklayan bir tefe"ül cetveli yer almaktadır. $\mathrm{Bu}$ cetvelde hangi harf ile ilgili bir açılama yapılmakta ise o harfle başlayan bir ayete veya ayet kısmına yer verilmesinin dikkat çekici bir özellik olduğu söylenebilir. Söz gelimi “"” harfinin açıklaması ele alınacak olursa falnâmede yer alan "Eger "l" gelse elā inne evliyā’allăhi lā-havfǜn'aleyhim ve lā-hüm yaḥzenūn bilgil ey fāl ıssı beşāret olsun saña Ḥak Te āāā çoḳ māl ve ni'met vire sevindüre vaḳtiñ hôş ola." ifadesinde "elā inne evliyāa'allāhi lā havfün' aleyhim ve lā-hüm yaḩzenūn" ayetinin ilk harfinin de "l" harfi olduğu görülecektir. Ancak bu açıklamanın istisnası olan şu durumlar da bulunmaktadır: " $"$ " harfi açıklanırken ayet kullanılmamış; "ض” harfi ile ilgili ayet “ظ” harfi ile başlatılmıştır. Ayrıca " 9 " harfi ile ilgili ayet kısmında yer alan “vehüve rahmeten” ifadesi, bir bütün olarak Kur'ân'da geçmemektedir. Bu sebeple ayet olan kısım, "raḥmeten” ş̧eklinde alınmıştır. “ظ” harfi, açıklanırken iki farklı ayetten kısmî iktibas yapılmıştır.

Metinde Arapça olarak yer alan bu ayet veya ayet kısımlarının Kur'ân-ı Kerim'deki hangi surenin kaçıncı ayeti olduğu, bu ayetlerin Türkçe tercümeleri ve varsa falnâme ve Kur'ân metni arasındaki farklılıklar dipnotta verilmiştir. Ayetlerin meallerine falnâme metninde yer alan Arapça bölüm kadar yer verilmiş; ayetlerin tamamının tercümesine yer verilmemiştir.

\section{Sonuç}

El yazması eserlerin bulunduğu kütüphanelerde kısa süreli bir katalog taramasıyla bile kendi içerisinde çok farklı özellikler barındıran yıldıznâme, seğirnâme, tefe "ülnâme ve daha birçok farklı isimle bu kapsama girebilecek esere rastlanması, bu tür eserlerin en azından yazıldıkları dönemlerde yaygın olduğunu göstermektedir.

İncelenen falnâmede abdestli olmak ve bazı duaları okumak gibi başka falnâmelerde de görülen ortak unsurlar bulunmaktadır. Ancak her falnâmede kendine özgü değerlendirme cetveli gibi farklı özellikler bulunması ve falnâmelerin daha çok tek nüsha olarak yazılmış olması, her eseri kendi özelinde değerlendirmeyi gerektirmektedir. Bu durum da türün kesin bir çerçevesini çizmeyi ve sistematiğini ortaya koymayı güçleştirmektedir.

Falnâmelerin yazıldıkları dönemin kimi kültürel ögelerine, toplumsal inançlarına, düşünce yapılarına ve değer yargılarına ait önemli ipuçları barındırdıkları görülmektedir. Sözgelimi incelenen falnâmede 
aceleci olmayıp sabırlı olmak, sıkıntılı zamanlarda sadaka vermek, akıllı insanlara danışmak tavsiye edilirken iyi adla anılmak gerektiğinin vurgulandığı da görülmektedir.

Falnâmenin değerlendirme cetveline dikkat edildiğinde cetvelde olumlu fal yorumunun çok daha fazla olduğu görülmektedir. Bu durumun tefe“ülün hayra yormak anlamına uygun olduğu söylenebilir.

Yorumu olumlu olan harflerde, mal ve nimete ulaşmak, sahib-i devletten iyilik görmek, âfetten, belalardan, korkudan uzak olmak, düşman üzere mansur ve muzaffer olmak, ululuk ve hürmete kavuşmak, evladından hayır görmek, uzak yerden armağan alacak olmak gibi yorumlar yer alırken olumsuz harf yorumlarında fal için tutulan niyetten kişiye ziyan değeceği, kendisi için hayırlı olmayacağından dolayı çıkılması düşünülen seferden vazgeçme, fal bakılan niyeti terk etme gibi ifadelerin yer aldı̆̆ı görülmektedir.

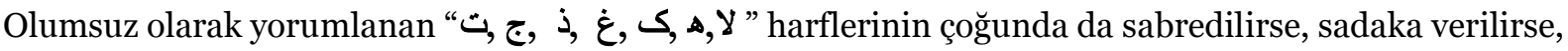
oruç tutulursa bu olumsuz durumdan kurtulmanın mümkün olacağının telkin edildiği; dolayısıyla fal yorumlarında genellikle kişiye ümit aşılandığı görülmektedir.

Incelenen metinde de görüldüğü üzere falnâme türü eserlerde müellif ismine genellikle rastlanmamasının fal işinin kanunla yasak olması ve toplum nezdinde de uygun görülmemesinden kaynaklanmış olabileceği düşünülebilir.

[1b]

\section{Hāz̄ā Kitāb-1 Fāl-nāme}

Ķaçan kim Ḳur'ān fālını açasın niyyet ḳılasın ḳıbleye ḳarşu dize çökesin andan āyete'l kürsī oḳıyasın andan șoñra üç kez șalavāt-1 şeriff oḳıyasın ve bu du'ẫ[y]ı üç kez oḳıyasın. Du'ā budur:

“Bismillāhi' r-rahmāni'r-rahịm Allāhümme inni tekabbeltü bi-kitābike'l-kerīm ve tevekkeltü 'aleyke fe-erini min-kitābike mā-hüve'l-mektūbi fï-sırrıke'l-meknūni fï-gaybike Allāhümme ente'l-hakkḷu enzelehü 'aleyke'lhakku"

Eger “"” gelse elā inne evliyāallāhi lā-ḩavfün'aleyhim ve lā-hüm yaḩzenūn (Yûnus 10/62) ${ }^{2}$ Bilgil ey fâl 1ss1 beşāret olsun saña Ḥaḳ Te`ālā çoḳ māl ve ni` met vire sevindüre vaḳtiñ ḩōş ola.

Eger “ب”" gelse billāhi ve melā’ iketihi ve kütübihi ve rüsulihi (Bakara 2/285) Bilgil ey fâl 1ssı șâhịb-i devletden saña menfac at ola eyligi dege gāayet ḩōş ola.

Eger “ت” gelse tāllāhi leḳad-erselnāa (Nahl 16/63) ${ }^{4}$ Bilgil ey fāl ıssı saña birḳaç gün șabır itmek gereksin dā’im oruç țutup namāz ḳılmaḳ gerek ve șadaḳa virgil yüz işüge tevbe ḳılasın.

Eger “ث”' gelse șiyābü sündüsin huḍrun ve-istebraḳun (İnsân 76/21) ${ }^{5}$ Bilgil ey fāl 1ssı kim āfetden ve ḳorḳudan ve guș̣̦adan halāṣ olasın [2a] Tañrı Te ālā çoḳ nic met vire ve nușret ve ululuḳ bulasın.

\footnotetext{
2 “Bilesiniz ki Allah'ın dostlarına hiçbir korku yoktur. Onlar üzülmeyeceklerdir de.” [Kur'ân meallerinde Diyanet İşleri Başkanlığının Kur'ân mealinden (haz. Altuntaş ve Şahin, 2012) ve şu internet sitesinden istifade edilmiştir: https://kuran.diyanet.gov.tr/mushaf (E.T. 23.06.2020)]

"Allah'a, meleklerine, kitaplarma ve peygamberlerine..."

"Allah'a ant olsun ki elbette peygamberler gönderdik...."

“...ince ve kalın ipekten yeşil elbiseler...” [Ayetin son kısmı, falnâmede “huḍin ve-istebrakin”” şeklinde yer almaktadır]
} 
Eger "ج" gelse cehenneme yașlevnehā ve-bi 'se'l-ḳarār (İbrâhim 14/29) ${ }^{6}$ Bilgil ey fāl 1ssı birḳaç gün șabır eyle ivmegil ögüt dutğıl ve uṣlu ve 'aḳıllu ādemiñ sözüñ dutg்ıl bu niyyetden saña ziyān deger vaḳtinde gitseñ varmaġıl ziyāna uğarsin.

Eger “ح” gelse ḥamīmün ḥamīmen (Me âric 70/10)7 Ey fāl ıssı āgāh olġıl birḳaç gün șabır eyle murādiña iresin.

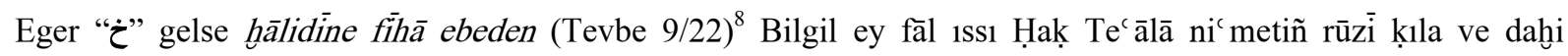
gușșadan ḳurtula, şāżımān ola[sın], ve haste ise[ñ] șag ola[sin].

Eger "د" gelse da`vāhüm fīhā sübḥānekellāhümme ve tehiyyetühüm fīhā selām (Yûnus 10/10) ${ }^{9}$ Ey fāl ıssı bilgil Hak $\mathrm{Te}^{c}$ ālā seni murādiña irişdüre dürlü ḳaygiudan ḳurtara düşmān üzerine manșūr ve muz̧affer olup şāz olasin Ḥaḳ Te ālāya şükür ḳılasın.

Eger “引” gelse žālike bi-ennāllahe (Muhammed 47/11) ${ }^{10}$ Bilgil ey 1ssı ġușṣadan ḳalmışsın uṣul olmayasın ve sefere niyyet itdükde zinhār gitmeyesin birḳaç gün șabır ḳılasın yohssa bir belāya ug̉rarsın.

Eger "’” gelse rabbenā enzil 'aleynā mā'ideten mine's-semā’ $i$ (Mâide 5/114) ${ }^{11}$ Ey fāl issı bilgil her ne içün niyyet ḳıldıñsa iyüdür iş başa çıḳar maḳșūduñ hạạṣl olur ḳagg̉udan ve gusșsadan ḳurtulasın.

Eger “j” [2b] gelse saña devletiñ ve hürmetiñ arta şazllı̣ [bulasın].

Eger "W" gelse selāmün 'aleyküm (Ra'd 13/24) 12 Ey fāl 1ssı bilgil beşāret olsun kim Allāhü Te âlā hațādan șaḳladı ḳayg̉udan ve gușṣadan emin olasın gümānsız rencden ḳurtulasın eger țopraḳ avuclarsañ Ḥaḳ $\mathrm{Te}^{\mathrm{c}} \bar{a} l a ̄$ emriyle altun ola ve sevinüp murādını bula[sın].

Eger “ش”' gelse şehru ramażānelleži ünzile fïhi'l-Kur ânnü (Bakara 2/185) ${ }^{13}$ Ey fāl 1ssı bilgil bu fāl şöyle delālet ider kim her ne ki hāacetiñ var ise revā ola murādıña iresin makṣūduñ ḥāṣıl ola baylıḳ bulasın şāą olup sevinüp ḳyāmet gününde dahi uçmaḳ şerbetiñ Ḥaḳ Te ālā içüre.

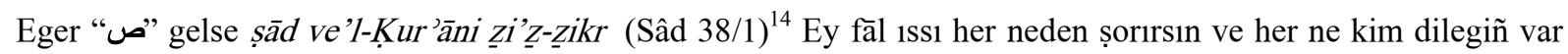
ise bulasin.

“ض ḍaraballāhu meselen lilleżine āmenū (Tahrîm 66/11) ${ }^{15}$ Ey fāl 1ssı bilgil bu niyyetden șaḳın saña ziyān degmesün ve dahi bu işde ta ciil ḳılmayasın yohssa azġunlug̉a ug̉rarsın birḳaç gün șabır tevaḳkuf itgil ve șadaḳa virgil șoñra murāda iresin.

Eger “ط’” gelse țā-hā mā-enzelnā 'aleyke'l- Kur ’āne li-teșkāa (Tā-Hā 20/1-2 ) ${ }^{16}$ Ey făl 1ssı bilgil guușṣadan āzād ola ve ḳayg̉udan ḳurtulasın gerek kim şükrāne viresin şāz olup maḳṣūduña iresin.

\footnotetext{
6 “...yaslanacakları cehenneme sürükleyenleri görmedin mi? O ne kötü duraktır. [Ayetin son kısmı, falnâmede " $f e-b i$ 'se' 1 karār" șeklinde yer almaktadır]

"...dost, dostunu (sormaz.)"

“Onlar, orada ebedî kalacaklardır.” [Birçok surede yer alan ifade için bir örnek verilmiştir.]

"Seni eksikliklerden uzak tutarız Allah'ım, aralarındaki esenlik dilekleri selâm (sözleridir.)"

"Bu böyledir çünkü Allah..."

"Ey Rabbimiz! Bize gökten bir sofra indir ki..."

"Selâm size" [Birçok surede yer alan ifade için bir örnek verilmiştir.]

"Ramazan ayı ki onda Kur’ân indirilmiştir."

"Sâd. Şanlı, şerefli Kur'ân'a andolsun (ki o, Allah sözüdür.)

"Allah, iman edenlere ise örnek gösterdi."

“Tâ-Hâ. Biz, Kur’ân'ı sana sıkıntı çekesin diye indirmedik. ” [Ayetin baş kısmı falnâmede “ṭā-hā mā-enzelnāhu” şeklinde yer almaktadır.]
} 
Eger "ظ’" gelse żlālühā ve züllilet (İnsân 76/14) ${ }^{17}$ [3a] kutūfühā dāniyetün (Hakka 69/23) ${ }^{18}$ Ey fāl ıssı eyü adlu olasin.

Eger " $\varepsilon$ " gelse 'amme yetesā’elūn (Nebe 78/1) ${ }^{19}$ Ey fāl 1ssı murādiñ hâaș̣l nic metiñ bol ola ve devletiñ arta ve

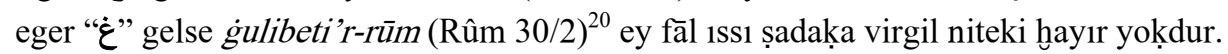

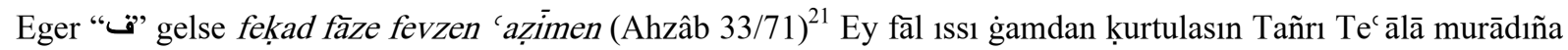
irdüre.

Eger “ق̄” gelse ḳāle hāzāā raḥmetün min-rabbī (Kehf 18/98)22 Ey fāl 1ssı og̉uldan ve ḳızdan çoḳ hayır göresin ve raḥmetüñ arta.

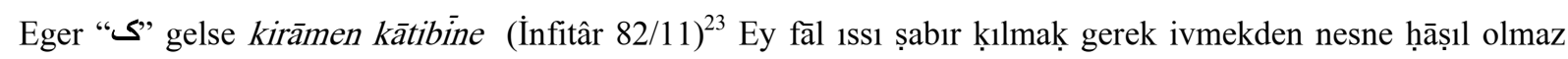
eger sefere gideyim dirsen șabır eylegil ziyāna uğrarsın.

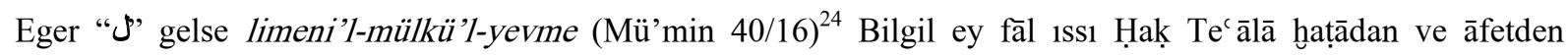
kurtardı düşmānıñ alt idüp hōş olup devletiñ arta.

Eger "’” gelse mālike'l mülki (Âl-i İmrân 3/26) $)^{25}$ Ey fāl ıssı bilgil bu niyyet kime ḳılduñ hōọs sevinüp şāz̄ olasın devletiñ ve bahtıñ saña yār ola hōoşluḳ bulasın.

Eger “ن’ gelse nūn ve'l-ḳalemi (Kalem 68/1) ${ }^{26}$ Ey fāl ıssı bilgil bu niyyet her ne içün dutduñ Ḥaḳ Te'ālā ḳolay getüre ammā birḳaç günden șabır ḳılı̀ıl șadaḳa vir kim maṭlūbuña irişesin.

Eger " 9 " gelse vehüve rahmeten (Nisâ 4/96) ${ }^{27}$ Ey făl 1ssı [3b] altun ve māl bulasın ve rāḥat olup makṣūduñ ḥāṣıl ola eylik bulasın Tañrı Te ālāya şükür ḳılġıl ırak yirden armag̉ān gele.

Eger "ه”" gelse hüvellezí ersele rasūlehü bi'l-hüdā (Tevbe 9/33) ${ }^{28}$ Ey fâl ıssı bilgil bu niyyetden döngil düşmān saña yavuz șanursa istiğfār it kim tā kim selāmet olasın.

Eger "ل'” gelse lā-reybe fīhi (Bakara 2/2) ${ }^{29}$ Ey fâl ıssı bilgil düşmānıñ yanındadur yoḳsa peşīmān olursın.

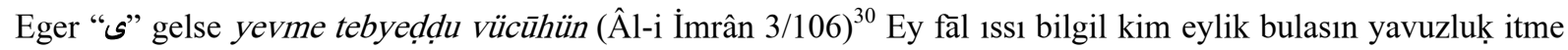
kim ḩayra iresin murādıñ ḥāṣıl ola inşāa allāhü Te āâā.

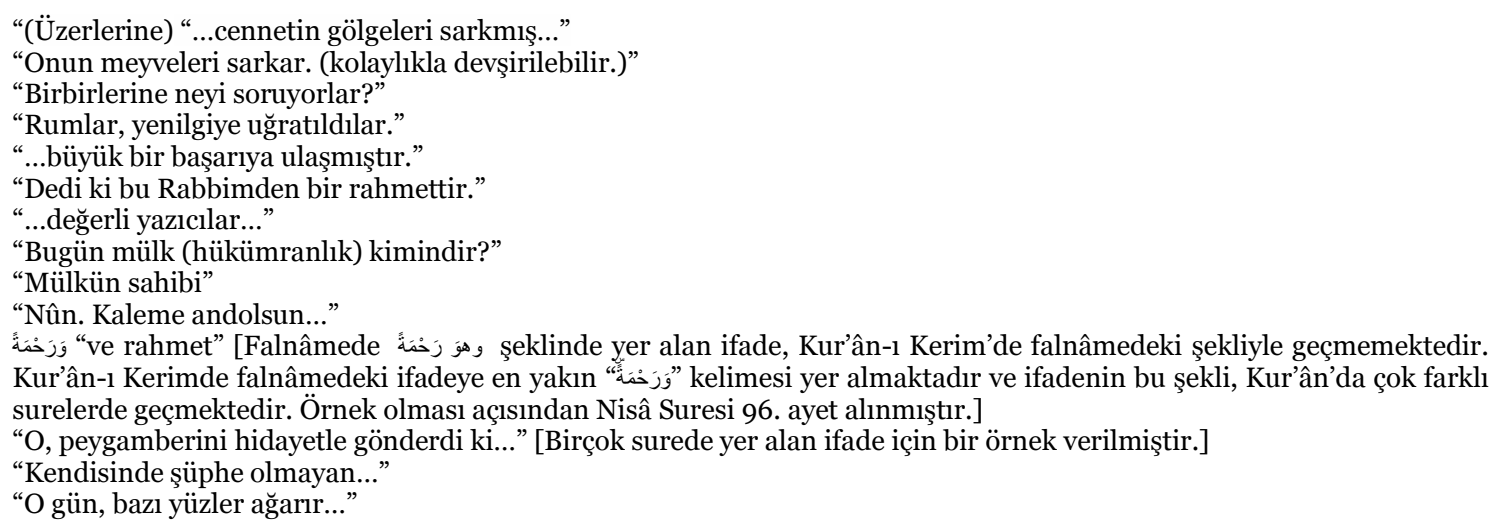




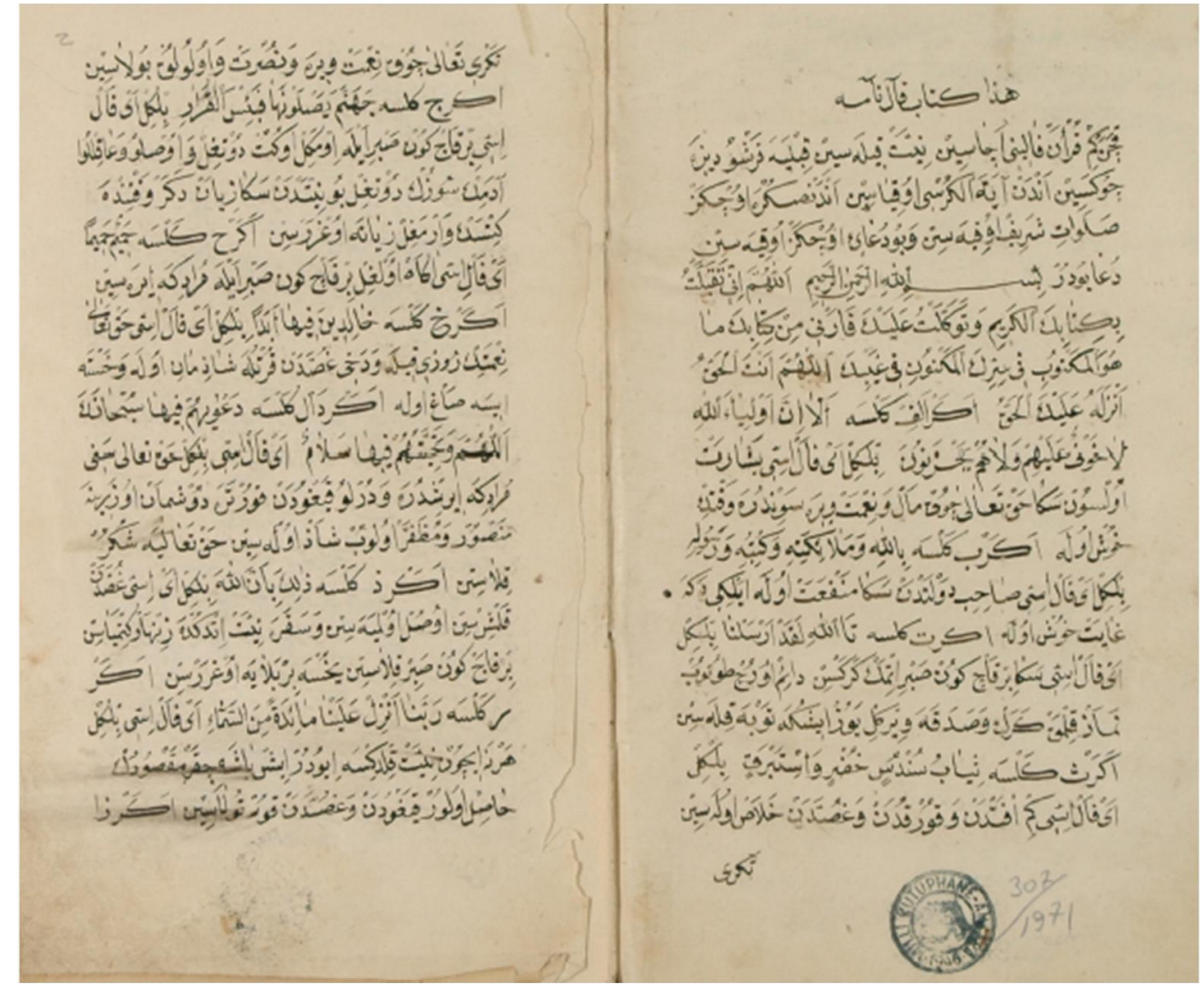

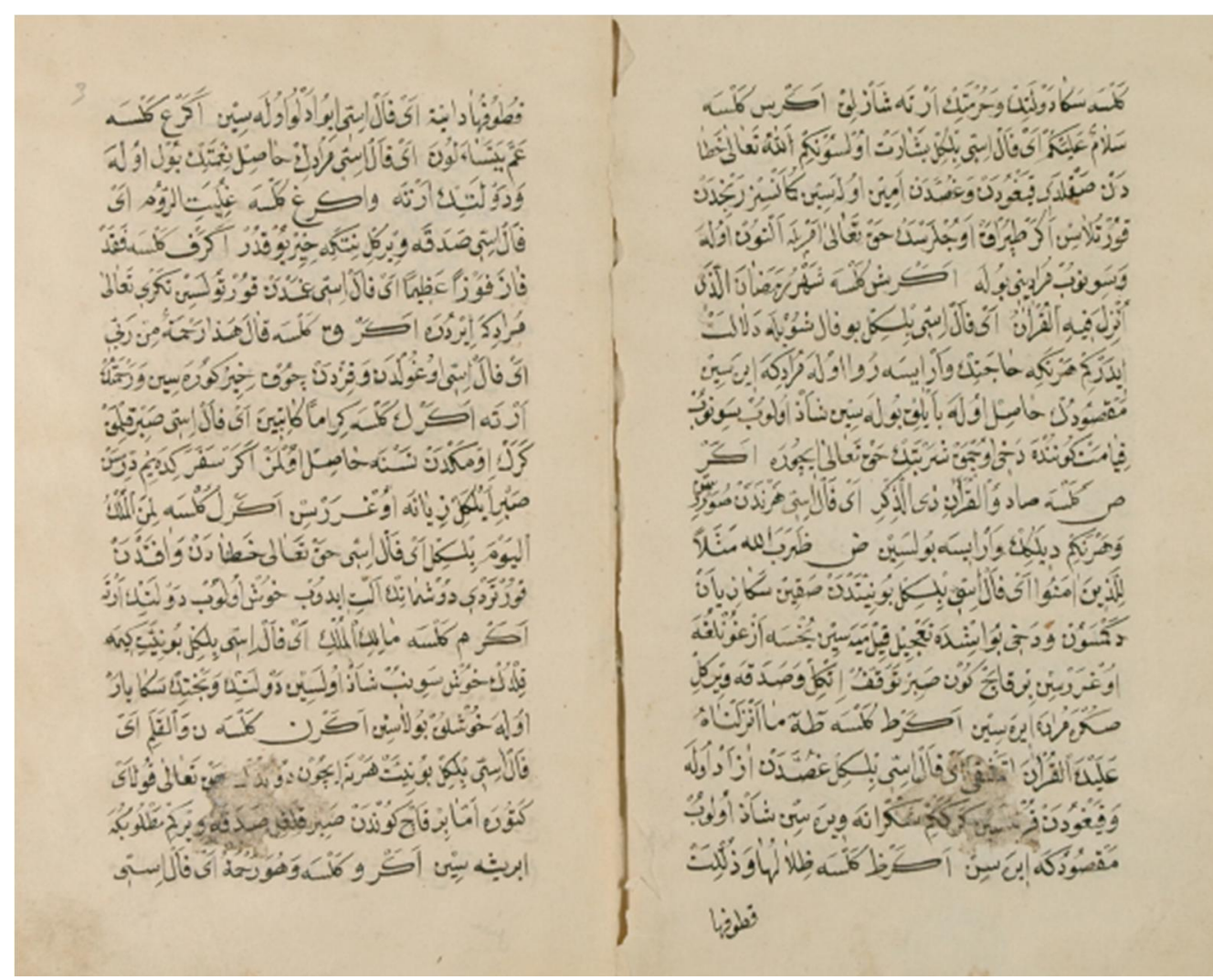




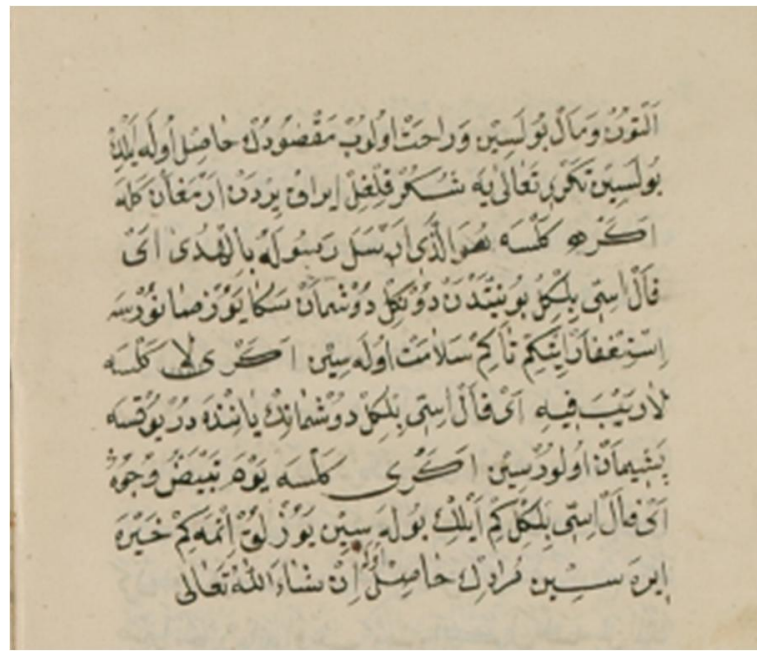

\section{Kaynakça}

Atalay, B. (1985). Divanü Lûgati’t-Türk Tercümesi, Ankara: Türk Dil Kurumu.

Aydın, M. (1995). “Fal”, TDV İslam Ansiklopedisi, İstanbul: TDV Yayınları, C.12, s. 134-138.

Bilkan, A. F. (2010). “Tefe'ül ile Ad Verme Geleneği ve Emir Timur’un Adı”, Millî Folklor, S. 85, s. 133137.

Caferoğlu, A. (1968). Eski Uygur Türkçesi Sözlüğü, İstanbul: Türk Dil Kurumu.

Çelebi, İ. (1995). "Fal”, TDV İslam Ansiklopedisi, İstanbul: TDV, C.12, s. 138-139.

Devellioğlu, F. (2013). Osmanlıca-Türkçe Ansiklopedik Lûgat, Ankara: Aydın.

Dikmen, M. ve Çetin K. (2016). "Klasik Türk Edebiyatında Tefe'ül Geleneği ve Kitap Falının Şiire Yansiması”, The Journal of Academic Social Science Studies, S. 49, s. 191-204.

Duvarcı, A. (1987). Türkiye'de Falcllk Geleneği ile Bu Konuda İki Eser "Falnâme-i Risâle-i Li Ca'fer-i Sadık ve "Tefe ülnâme", Ankara: Gazi Üniversitesi Sosyal Bilimler Enstitüsü Yayımlanmamış Doktora Tezi.

Ersoylu, H. (1981). "Fal, Falnâme ve Fâl-ı Reyhân-ı Cem Sultan”, İslâm Medeniyeti Mecmuası, s. 6981.

Ersoylu, H. (1997). "Fal, Fal-nâme ve Bir Çiçek Falı: Der Aksâm-ı Ezhar”, Türkiyat Mecmuası, C.20, s. 195-254.

Ertaylan, İ. H. (1951). Falnâme, İstanbul: İstanbul Üniversitesi.

Gülhan, A. (2015). “Türk Edebiyatında Fal ve İsimlerle İlgili Bir Manzum Falname Örneği”, Divan Edebiyatı Araşttrmaları Dergisi, S.15, s. 195-222.

Gür, N. (2012). "Osmanlı Fal Geleneği Bağlamında Yıldıznâme, Falnâme ve Tâlinâme Metinleri”, Millî Folklor, S. 96, s.202-215.

Hançerlioğlu, O. (2000). Dünya İnançları Sözlüğü, İstanbul: Remzi.

İnan, A. (1986). Tarihte ve Bugün Şamanizm Materyallar ve Araştırmalar, Ankara: Türk Tarih Kurumu.

Karataş, T. (2001). Ansiklopedik Edebiyat Terimleri Sözlüğü, İstanbul: Perşembe.

Kur'ân-ı Kerim Meali (2012). (haz. H. Altuntaş ve M. Şahin), Ankara: Diyanet İşleri Başkanlığı.

Kurnaz, C. (1997). “Zaîfi’nin “Fâl-ı Murgân'ı”, Divan Edebiyatı Yazıları, Ankara: Akçă̆, s. 183-205.

Macdonald, D. B. (1988). "Fal”, İslam Ansiklopedisi, Ankara: Millî Ĕ̆itim Bakanlı̆̆ı, C.4, s.499-45o. 
Öz, M. (1995). “Ezlâm”, TDV İslam Ansiklopedisi, İstanbul: TDV Yayınları, C.12, s. 67.

Pakalın, M. Z. (1993). "Fal”, Osmanl Tarih Deyimleri ve Terimleri Sözlüğü, İstanbul: Millî Eğitim Bakanlığı, C.1, s. 565-586.

Pala, İ. (1995). Ansiklopedik Divan Şüri Sözlüğü, Ankara: Akçă̆.

Sahîh-i Buhârî ve Tercemesi (1998). (çev. M. Sofuoğlu), İstanbul: Ötüken Yayınları, C.3, C.12.

Sezer, S. (1988). Osmanlıda Fal ve Falnâmeler, İstanbul: Milliyet Yayınları.

Sümbüllü, Y. Z. (2008). "İlm-i Tefe'ül ve Tefe'ül-nâme (Kur'ân Falı) Üzerine Bir Değerlendirme”, Uluslararası Sosyal Araştırmalar Dergisi, S. 1/2 Kış, s. 383-391.

Şanll, İ. (2003). "XVI. Yüzyll Divan Şâiri Fedâyî ve Fâl-nâme-i Kur'ân-ı 'Azîm'i”, Bursa: Uludağ Üniversitesi Fen-Edebiyat Fakültesi Sosyal Bilimler Dergisi, S. 5, s. 161-178.

Şenödeyici, Ö. ve Koşik H. S. (2015). "En Muteber Kaynaktan Gaybı Öğrenmek: Bir Kuran Falı Manzumesi”, Littera Turca Journal of Turkish Language and Literature, S. 1, s. 71-96.

Şenödeyici, Ö. ve Koşik H. S. (2017). Osmanlının Gizemli İlimleri-1 Kur’ân Falları ve Uzun Fïrdevsîye Ait Bir Örnek, İstanbul: Kesit.

Temizkan, M. (2007). "Bir Kur'ân Falı", Millî Folklor, S. 74, s. 70-74.

Topal, S. A. (2011). “Gaybın Bilgisi Allah Katındadır”, Kur'ândan Öğütler-1 (haz. Y. Yiğit vd.), Ankara: Diyanet İşleri Baş̧anlığ1, s. 250-251.

Uzun, M. İ. (1995). "Falnâme”, TDV İslam Ansiklopedisi, İstanbul: TDV Yayınları, C.12, s. 141-145.

Vural, H. (2017). "Fal Bakma Geleneği ve Bir Fâl-ı Kur'ân", Gaziosmanpaşa Üniversitesi İlahiyat Fakültesi Dergisi, S. 2, s. 95-114.

Yıldız, Â. (2010). “Manzum Bir Kur’ân Falı”, İstem Dergisi, S. 16, s. 181-198.

\section{Internet kaynakları}

https://kuran.diyanet.gov.tr/mushaf (Erişim Tarihi: 23.06.2020) 